\title{
Role of microRNAs in Hemophilia and Thrombosis in Humans
}

\author{
Katarzyna I. Jankowska ${ }^{1}$, Zuben E. Sauna ${ }^{2}$ and Chintamani D. Atreya ${ }^{1, *}$ \\ 1 OBRR/DBCD/LCH in the Center for Biologics Evaluation and Research, US Food and Drug Administration, \\ Silver Spring, MD 20993, USA; katazyna.jankowska@fda.hhs.gov \\ 2 OTAT/DPPT/HB in the Center for Biologics Evaluation and Research, US Food and Drug Administration, \\ Silver Spring, MD 20993, USA; zuben.sauna@fda.hhs.gov \\ * Correspondence: Chintamani.Atreya@fda.hhs.gov
}

Received: 4 May 2020; Accepted: 14 May 2020; Published: 20 May 2020

check for updates

\begin{abstract}
MicroRNAs (miRNA) play an important role in gene expression at the posttranscriptional level by targeting the untranslated regions of messenger RNA (mRNAs). These small RNAs have been shown to control cellular physiological processes including cell differentiation and proliferation. Dysregulation of miRNAs have been associated with numerous diseases. In the past few years miRNAs have emerged as potential biopharmaceuticals and the first miRNA-based therapies have entered clinical trials. Our recent studies suggest that miRNAs may also play an important role in the pathology of genetic diseases that are currently considered to be solely due to mutations in the coding sequence. For instance, among hemophilia A patients there exist a small subset, with normal wildtype genes; i.e., lacking in mutations in the coding and non-coding regions of the $F 8$ gene. Similarly, in many patients with missense mutations in the $F 8$ gene, the genetic defect does not fully explain the severity of the disease. Dysregulation of miRNAs that target mRNAs encoding coagulation factors have been shown to disturb gene expression. Alterations in protein levels involved in the coagulation cascade mediated by miRNAs could lead to bleeding disorders or thrombosis. This review summarizes current knowledge on the role of miRNAs in hemophilia and thrombosis. Recognizing and understanding the functions of miRNAs by identifying their targets is important in identifying their roles in health and diseases. Successful basic research may result in the development and improvement of tools for diagnosis, risk evaluation or even new treatment strategies.
\end{abstract}

Keywords: microRNAs (miRNAs); thrombosis; bleeding disorders; coagulation factors; hemophilia

\section{Introduction}

According to the National Hemophilia Foundation, bleeding disorders are a group of disorders that share the inability to form a proper blood clot; they are characterized by extended bleeding after injury, surgery, trauma or menstruation. The human body produces 13 clotting factors also known as coagulation factors and any deficiency in any one of them can lead to either a minor, moderate or severe bleeding disorder (https://www.hemophilia.org/Bleeding-Disorders/What-is-a-Bleeding-Disorder).

Conversely, a blood clot could result in blood vessels due to high levels of some of the clotting factors (coagulation factors VII, VIII, IX, XI and von Willebrand factor), which is known as thrombosis, a term originated from Greek, meaning a lump or clump (https://www.medicinenet.com/script/main/ art.asp?articlekey=25023).

Both deficiency of and excessive production of clotting factors can result in a disease pathology. Maintenance of homeostasis vis-à-vis clotting factors is thus critical for avoiding pathologies. Several cellular regulatory mechanisms, operating at several levels are involved in the regulation of gene expression. For example, regulation can occur at the gene transcriptional level 
(mRNA size, polyadenylation and copy number), posttranscriptional level (translational interference) and posttranslational level (phosphorylation, glycosylation, etc.).

In the last few decades, microRNA (miRNA)-mediated control of mRNA expression has emerged as a key biological mechanism regulating gene expression. The miRNAs are small noncoding RNAs that bind to the $3^{\prime}$ untranslated region (UTR) of target mRNAs and through a complex process affect gene expression [1-3]. miRNAs exert their influence on gene expression by either terminating [4,5], or fine-tuning $[6,7]$.

In the case of the rare bleeding disorder hemophilia A (HA), miRNAs have been shown to directly target and down-regulate the F8 gene that codes for Factor VIII (FVIII) $[8,9]$.

The pathogenesis of thrombosis is more complex and can be triggered by numerous inherited or environmental factors (or a combination of both) leading to arterial or venous occlusion.

The cumulative effect is abnormalities in the vessel wall (e.g., atherosclerosis), blood flow or blood coagulation, which in turn may lead to alterations in platelet function, levels of coagulation factors or fibrinolysis. In addition, thrombosis may be triggered by metabolic or hormonal factors as well as by endothelial dysfunction and inflammation [10]. Among the many risk factors for thrombosis, levels of FVIII that are $>1.5$ times the normal plasma levels (0.5-1.5) have shown a strong association with venous thrombosis [11].

\section{Bleeding Disorders and miRNAs}

A growing body of research indicates that miRNAs play a role as modulators of the hemostatic system by direct or indirect interaction with the mRNAs that encode proteins involved in coagulation. Dysregulation of these miRNAs can lead to expression of coagulation proteins that are outside the relatively narrow range observed in healthy individuals which leads to either bleeding disorders or thrombosis (Table 1).

Table 1. MicroRNAs (MiRNAs) that May Target Protein Involved in Coagulation Cascade Which Dysregulation May Lead to Bleeding Disorders or Thrombosis.

\begin{tabular}{ccc}
\hline Target Gene & miRNA & References \\
\hline \multirow{3}{*}{$F 1$} & miR-18a & {$[12]$} \\
\cline { 2 - 3 } & miR-211 & {$[13]$} \\
\cline { 2 - 3 } & miR-218 & {$[14]$} \\
\cline { 2 - 3 } & miR-29a/b/c & {$[14]$} \\
\hline \multirow{2}{*}{$F 1(F G A)$} & $\mathrm{miR}-365$ & {$[14]$} \\
\hline & $\mathrm{miR}-193 \mathrm{~b}-3 \mathrm{p}$ & {$[15]$} \\
\hline & $\mathrm{miR}-194-5 \mathrm{p}$ & {$[16]$} \\
\hline & $\mathrm{miR}-186$ & {$[16]$} \\
\cline { 2 - 3 } & $\mathrm{miR}-3133$ & {$[16]$} \\
\cline { 2 - 3 } & $\mathrm{miR}-3173$ & {$[16]$} \\
\hline & $\mathrm{miR}-434$ & {$[14]$} \\
\hline
\end{tabular}


Table 1. Cont.

\begin{tabular}{|c|c|c|}
\hline Target Gene & miRNA & References \\
\hline \multirow{5}{*}{$F 1(F G B) *$} & miR-29b-1-5p & [16] \\
\hline & miR-4294 & [16] \\
\hline & miR-627 & [16] \\
\hline & miR-759 & [16] \\
\hline & miR-924 & [16] \\
\hline \multirow{4}{*}{$F 1\left(F G G \_A\right)$} & miR-151a-5p & [15] \\
\hline & miR-193-5p & [15] \\
\hline & miR-452-5p & [15] \\
\hline & miR-99b-3p & [15] \\
\hline \multirow{5}{*}{$F 7$} & miR-134 and & [19] \\
\hline & miR-181a & [19] \\
\hline & miR-195-5p & [20] \\
\hline & $\operatorname{miR}-19 a / b-3 p$ & [15] \\
\hline & MiR-885-5p & [20] \\
\hline \multirow{19}{*}{ F8 } & let-7i-5p & [8] \\
\hline & miR-1246, & [9] \\
\hline & miR-128-3p & [8] \\
\hline & $\operatorname{miR}-144-5 p$ & [8] \\
\hline & miR-15b-3p & [8] \\
\hline & miR-181d & [9] \\
\hline & miR-18a-5p & [15] \\
\hline & $\mathrm{miR}-30 \mathrm{c}$ & [8] \\
\hline & miR-30e-3p & [15] \\
\hline & miR-34-5p & [15] \\
\hline & $\mathrm{miR}-374 \mathrm{~b}$ & [8] \\
\hline & miR-4521 & [9] \\
\hline & miR-454-3p & [15] \\
\hline & miR-483-3p & [8] \\
\hline & miR-532-5p & [15] \\
\hline & miR-6803-3p, & [8] \\
\hline & miR-7-5p & [15] \\
\hline & miR-874-3p & [15] \\
\hline & miR-1297 & [21] \\
\hline \multirow{4}{*}{$F 8^{*}$} & miR-26a-5p & [21] \\
\hline & miR-26b-5p & [21] \\
\hline & $\mathrm{miR}-34 \mathrm{a} / \mathrm{c}$ & [16] \\
\hline & miR-449a/b & [16] \\
\hline \multirow{2}{*}{$F 9$} & miR-128 & [22] \\
\hline & miR-125 & [22] \\
\hline
\end{tabular}


Table 1. Cont.

\begin{tabular}{|c|c|c|}
\hline Target Gene & miRNA & References \\
\hline$F 10$ & miR-24 & [23] \\
\hline \multirow{13}{*}{$F 11$} & miR-103a-3p & [15] \\
\hline & $\operatorname{miR}-1255 a$ & [15] \\
\hline & miR-145 & [24] \\
\hline & miR-148b-3p & [15] \\
\hline & miR-151a-3p & [15] \\
\hline & miR-15b-5p & [15] \\
\hline & miR-181a & [24] \\
\hline & miR-181b-5p & [15] \\
\hline & miR-24-3p & [15] \\
\hline & miR-30a-3p & [15] \\
\hline & miR-30d-3p & [15] \\
\hline & miR-96-5p & [15] \\
\hline & miR-126-3p & [20] \\
\hline \multirow{9}{*}{$F 11$ * } & miR-137 & [16] \\
\hline & miR-1975 & [16] \\
\hline & miR2355 & [16] \\
\hline & $\mathrm{miR}-4286$ & [16] \\
\hline & miR-513a-3p & [16] \\
\hline & miR-544 & [16] \\
\hline & miR-622 & [16] \\
\hline & miR-889 & [16] \\
\hline & miR-93-5p & [16] \\
\hline \multirow{3}{*}{ PROS1 } & miR-195-5p & [20] \\
\hline & MiR-494 & [25] \\
\hline & MiR-885-5p & [20] \\
\hline \multirow{2}{*}{ PROS1 * } & $\operatorname{miR}-26-5 p$ & [16] \\
\hline & miR-375 & [16] \\
\hline \multirow{5}{*}{$T F$} & miR-103-3p & [26] \\
\hline & miR-145 & [27] \\
\hline & miR-181b & [28] \\
\hline & $\operatorname{miR}-19 b$ & [29] \\
\hline & miR-223 & [30] \\
\hline \multirow{2}{*}{ TFPI } & $\mathrm{miR}-27 \mathrm{a} / \mathrm{b}$ & [31] \\
\hline & $\operatorname{miR}-494$ & [31] \\
\hline
\end{tabular}


Table 1. Cont.

\begin{tabular}{ccc}
\hline Target Gene & miRNA & References \\
\hline \multirow{2}{*}{ TFPI * } & miR-200a/b & {$[16]$} \\
\cline { 2 - 3 } & miR-2355 & {$[16]$} \\
\cline { 2 - 3 } & miR-429 & {$[16]$} \\
\cline { 2 - 3 } & miR-4302 & {$[16]$} \\
\hline \multirow{2}{*}{$V W F$} & miR-605-24 & {$[16]$} \\
\hline ADAMS13 & miR-103-3p & {$[26]$} \\
\hline
\end{tabular}

\subsection{Hemophilia}

Bleeding disorders such as HA and hemophilia B (HB), are X-linked genetic diseases cause by deficiency of coagulation factor VIII and coagulation factor (FIX), mainly due to genetic perturbations or variations in the $F 8$ and $F 9$ genes [34]. In a small subset of screened hemophilia patients, $F 8$ and F9 gene do not exhibit any mutations. In approximately $0.6 \%$ of severe HA, $2.9 \%$ of mild-moderate HA patients and $1.1 \%$ of mild to moderate HB patients no variants were identified. Nonetheless these individuals showed lower levels of FVIII or FIX consistent with the severity of the disease, suggesting that the expression of these coagulation factors is controlled by mechanisms besides genetic mutations in $F 8$ and $F 9$ genes in the disease manifestation.

\subsubsection{Hemophilia A}

While in most cases HA is associated with mutations in the $F 8$ gene, several lines of evidence indicate a role of miRNAs in FVIII deficiency. We carried out a microarray analysis of blood samples from 15 HA patients with or without inhibitors (inhibitory anti-FVIII antibodies) to test the hypothesis that dysregulation of miRNAs that control immune response genes contribute to inhibitor development in some HA patients; we discovered that upregulation of miR-1246, miR-4521 and miR-181d in HA patients [9]. We also demonstrated that miR-1246 has a potential target site in $3^{\prime}$ UTR of FVIII as predicted by Target Scan and can modulate $F 8$ expression in lymphoblastoid cells that endogenously express FVIII. Thus, we inadvertently discovered that impeded regulation of FVIII expression could contribute to the HA phenotype. A miRNA mediated inhibition of FVIII leading to HA is best evaluated in the ultra-rare patients where mutations in the coding and non-coding $F 8$ sequences are not a confounding factor.

Next generation sequencing analysis of blood samples from severe and mild HA patients with no genetic defect in coding or non-coding regions revealed a group of 8 miRNAs significantly dysregulated compare to healthy donors; two miRNAs, miR-128-3p and let-7i-5p were down-regulated and 6 miRNAs (miR-144-5p, miR-374b-5p, miR-30c-5p, miR-6803-3p, miR-15b-3p and miR-483-3p) were up-regulated in HA patients; from this pool, miR-30c and miR-374b were demonstrated to target $3^{\prime}$ UTR of FVIII [8]. Both, miR-30c and miR-374b were shown to target and regulate expression of the F8 gene in lymphoblastoid cells and, downregulate FVIII protein levels in lymphoblastoid cells and the Human Umbilical Vein Endothelial Cells (HUVECs). Importantly, inhibition of endogenous miR-30c in the HUVEC cell line resulted in a significant increase of endogenous FVIII. These studies confirmed a role for miRNAs in regulating FVIII levels and indicated that dysregulation of miRNAs could contribute to FVIII deficiency. The finding that controlling expression of miRNAs can modulate FVIII protein levels in cell is important as it suggests a potential therapeutic strategy for the clinical use of miRNAs [35]. 
It is also possible that genetic variations in miRNA target sites that disrupt the formation of the miRNA-mRNA duplex can contribute to FVIII deficiency. Consistent with this postulate; several mutations in the $3^{\prime}$ UTR of $F 8$ have been associated with HA [36] and occur in $~ 0.1 \%$ of patients [34]. Intriguingly, mutation in $F 83^{\prime}$ UTR associated with HA are very close to the target sites for miR-26a-5p, miR-26b-5p and miR-1297 [21].

\subsubsection{Hemophilia B}

The role of miRNA in hemophilia B has not yet been extensively studied. It is however interesting to note that $3^{\prime}$ UTR polymorphisms of coagulation factor IX are more frequent than those identified in FVIII and occur in $1.4 \%$ of severe and $1.1 \%$ mild-moderate HB patients [34]. Thus, the postulate that FIX levels are affected in some HB patients via miRNA dysregulation warrants further investigation.

In addition, recent studies show that miR-128 and miR-125 may play a role in the expression of a F9 gene variant with a nonsense mutation (E7a (nt $34 \mathrm{G}>\mathrm{T}$ in exon 7) and E7b (nt $52 \mathrm{G}>\mathrm{T}$ in exon 7). It has been proposed that the miRNAs suppress the nonsense-mediated mRNA decay (NMD) pathway which degrades the mRNAs containing the premature termination codon (PTC) [22]. These miRNAs provide a potential therapeutic avenue for $\mathrm{HB}$ patients with nonsense mutations who represent $\sim 24 \%$ of severe HB patients [34].

\subsubsection{Hemophilia C}

Factor XI (FXI) deficiency, known also as hemophilia C can be caused by more than 220 mutations in the F11 gene [37]. The deficiency of FXI does not always cause spontaneous bleeding, but rather increases the risk of bleeding during hemostatic events [38]. The mechanism of FXI regulation is complex and still not fully understood, however a recent study suggests that $F 11$ gene expression is regulated by miRNAs [39]. Overexpression or suppression of miR-181a in the liver cell line, HepG2 resulted on dysregulation of FXI. The direct interaction of this miRNA with F11 3'UTR was confirmed by using in silico algorithms and in an in vitro study using the luciferase assay. Moreover, F11 mRNA levels were inversely and significantly correlated with miR-181a-5p levels in 114 healthy livers [39]. Consequently, up-regulation of miR-181a may cause a decrease in FXI expression and FXI deficiency in the plasma. An additional study on the genetic regulation of FXI predicted 11 miRNAs including miR-145 and miR-181a as potential post-transcriptional regulators of FXI [24]. Further evaluation of these two miRNAs via luciferase assay confirmed the direct interaction of miR-145 and miR-181a with F11 3'UTR.

\subsection{Von Willebrand Disease}

Von Willebrand disease (VWD) caused by genetic mutations in the Von Willebrand factor (VWF) gene is the most common inherited hemostatic disorder and associated with over 560 mutations and 217 polymorphisms in VWF gene [19]. Polymorphisms in the $5^{\prime}$ and $3^{\prime}$ UTR regions of the VWF gene have been reported but the effect of miRNAs on different variants has not been studied. Interestingly, a study on blood samples from 115 diabetic patients and 112 healthy donors identified a correlation between high glucose level, elevated levels of mature VWF and lower expression of miR-24 compared to healthy controls [32]. The direct association of miR-24 with the VWR gene was confirmed by prediction analysis and reporter gene assays using a luciferase vector linked to either a wild-type $V W F$ $3^{\prime}$ UTR or the mutated miR-24 binding site. Finally, studies using a diabetic mouse models and human and mouse endothelial cells further confirmed that suppression of miR-24 increases the expression of VWF while overexpression of miR-24 decreases WVF expression.

An additional study found that miR-24 associates with the $3^{\prime}$ UTR of VWF in osteosarcoma (OS) tissues collected from 84 patients [33]. Decreased expression of miR-24 in human OS tissues was closely associated with tumor metastasis and OS cell progression.

If these studies are replicated and the mechanistic role of VWF as a biomarker for diabetes and OS are elucidated; modulating miRNA levels offers an alternative clinical strategy for the clinical 
management of these diseases. As these two studies have shown that miR-24 regulates expression, maturation and secretion of VWF, additional studies to evaluate the role of miRNAs in control on VWF expression and in VWD are warranted.

\section{Thrombosis and miRNA}

Thrombosis, that can occur in the veins or the arteries is a leading cause of death worldwide [40]. This complex disease is associated with both environmental and genetic risk factors. In addition, the role of miRNA in thrombosis has been recently accentuated (Table 2).

Table 2. MiRNAs Associated with Different Types of Thrombosis.

\begin{tabular}{|c|c|c|c|}
\hline & miRNA & Target Gene & References \\
\hline \multirow{16}{*}{ DVT } & miR-103a-3p & CXCL12 & [26] \\
\hline & miR-126 & PIK3R2 & [41] \\
\hline & miR-136-5p & & [42] \\
\hline & miR-150 & SRCIN1 & [43] \\
\hline & \multirow{3}{*}{ miR-195 } & $\mathrm{Bcl}-2$ & [44] \\
\hline & & GAPA & [45] \\
\hline & & & [46] \\
\hline & miR-205 & PTEN & [47] \\
\hline & miR-21 & FASL & [48] \\
\hline & MiR-26a & PRKCD & [49] \\
\hline & $\mathrm{miR}-320 \mathrm{a} / \mathrm{b}$ & & [50] \\
\hline & miR-338-5 & & [51] \\
\hline & miR-424-5p & & [42] \\
\hline & miR-483-3p & SRF & [52] \\
\hline & miR-532 & & [46] \\
\hline & miR-582 & & [46] \\
\hline \multirow{20}{*}{$\mathrm{PE}$} & let-17b & ET-1, TGFBR1 & [53] \\
\hline & miR-106b & & [53] \\
\hline & miR-1233 & & [54] \\
\hline & miR-1260 & & [53] \\
\hline & miR129-5p & & [53] \\
\hline & miR-134 & & [55] \\
\hline & miR-140-3p & & [53] \\
\hline & miR-185 & & [53] \\
\hline & miR-1908 & & [53] \\
\hline & miR-22 & & [53] \\
\hline & miR-221 & & [56] \\
\hline & $\mathrm{miR}-27 \mathrm{a} / \mathrm{b}$ & & [57] \\
\hline & miR-28 & & [58] \\
\hline & $\mathrm{miR}-320 \mathrm{a} / \mathrm{b} / \mathrm{c}$ & & [53] \\
\hline & miR-423-5p & & [53] \\
\hline & miR-483-5p & & [53] \\
\hline & $\mathrm{miR}-486$ & & [53] \\
\hline & miR-602 & & [53] \\
\hline & miR-93 & & [53] \\
\hline & miR-933 & & [53] \\
\hline
\end{tabular}


Table 2. Cont.

\begin{tabular}{|c|c|c|c|}
\hline & miRNA & Target Gene & References \\
\hline \multirow{24}{*}{ VTE } & \multirow{2}{*}{ miR-103a-3p } & & [59] \\
\hline & & & [60] \\
\hline & miR-106a-5p & & [60] \\
\hline & miR-10b-5p & & [59] \\
\hline & miR-145 & & [61] \\
\hline & miR-15b-5p & & [60] \\
\hline & miR-191-5p & & [59] \\
\hline & miR-195 & & [61] \\
\hline & miR-197-3p & & [60] \\
\hline & miR-199b-3p & & [59] \\
\hline & miR-21-5p & & [60] \\
\hline & miR-222-3p & & [60] \\
\hline & miR-26b-5p & & [60] \\
\hline & miR-27b-3p & & [60] \\
\hline & miR-301a-3p & & [59] \\
\hline & miR-30c-5p & & [60] \\
\hline & $\mathrm{miR}-320 \mathrm{a} / \mathrm{b}$ & & [59] \\
\hline & miR-361-5p & & [60] \\
\hline & miR-423-5p & & [59] \\
\hline & miR-424-5p & & [59] \\
\hline & miR-483-3p & & [61] \\
\hline & miR-532 & & [61] \\
\hline & miR-532-5p & & [60] \\
\hline & miR-652-3p & & [60] \\
\hline \multirow{19}{*}{ AT } & miR-10a & & [62] \\
\hline & miR-124a & & [63] \\
\hline & miR-125a & & [63] \\
\hline & \multirow{5}{*}{$\mathrm{miR}-126$} & VCAM-1, CXCL12 & [64] \\
\hline & & & [65] \\
\hline & & & [66] \\
\hline & & & [62] \\
\hline & & & [67] \\
\hline & miR-146a & & [63] \\
\hline & & & [68] \\
\hline & \multirow{4}{*}{ miR-155 } & & [65] \\
\hline & & & [63] \\
\hline & & & [62] \\
\hline & & & [67] \\
\hline & miR-17 & & [67] \\
\hline & miR-21 & & [68] \\
\hline & miR-210 & & [68] \\
\hline & \multirow{2}{*}{ miR-221 } & & [65] \\
\hline & & & [62] \\
\hline
\end{tabular}


Table 2. Cont.

\begin{tabular}{|c|c|c|c|}
\hline & miRNA & Target Gene & References \\
\hline \multirow{12}{*}{ AT } & \multirow{2}{*}{ miR-222 } & & [65] \\
\hline & & & [62] \\
\hline & \multirow{3}{*}{ miR-223 } & ICAM-1 & [69] \\
\hline & & & [62] \\
\hline & & & [13] \\
\hline & miR-28 & & [62] \\
\hline & miR-320b & ICAM-1 & [27] \\
\hline & miR-34a & & [68] \\
\hline & miR-431 & & [62] \\
\hline & miR-490 & & [62] \\
\hline & miR-9 & & [62] \\
\hline & miR-92a & & [68] \\
\hline
\end{tabular}

\subsection{Venous Thromboembolism}

Venous thrombosis that includes both deep vein thrombosis (DVT) and pulmonary embolism (PE) is one of the major causes of cardiovascular disease. DVT is a serious condition that occurs when a blood clot forms in a vein located deep inside a patient; it typically forms in the foot, ankle and leg as well as the arm. While it is commonly accepted that the venous thrombosis is associated with numerous environmental factors genetic perturbations that cause loss of function in antithrombin, protein $S$, protein $C$ or high level of coagulation factors have also been associated with clot formation in veins [70]. The evaluation of plasma from 39 venous thromboembolism (VTE) patients with recurrent VTE compared to 39 control non-recurrent VTE patients found that elevated level of: miR-15b-5p, miR-222-3p, miR-26b-5p, miR-532-5p, miR-21-5p and miR-30c-5p and lower levels of miR-106a-5p, miR-197-3p, miR-652-3p, miR-361-5p, miR-27b-3p and miR-103a-3p were significantly associated with risk of VTE recurrence [60]. Another study on 20 patients with a history of unprovoked VTE showed an increase in expression of miR-10b-5p, miR-320a/b, miR-424-5p and miR-423-5p, and a decrease in expression of miR-103a-3p, miR-191-5p, miR-301a-3p and 199b-3p in patient plasmas compare to healthy controls [59]. Furthermore, a meta-analysis that included a total of 1057 individuals suggested that miR-1233, miR-134, miR-145, miR483-3p, miR-532 and miR-195 may serve as VTE diagnostic biomarkers [61].

\subsubsection{Deep Vein Thrombosis}

Numerous reports suggest a role for miRNAs in the pathogenesis of venous thrombo-embolism and some of these studies have found a strong correlation between differential miRNAs expression and the symptoms of venous thrombosis [71,72]. The majority of miRNAs associated with deep vein thrombosis has been shown to be expressed by endothelial cells (ECs) and are associated with the normal function(s) of ECs [44]. The process by which endothelial progenitor cells (EPCs), i.e., bone marrow-derived cells that have the capacity to migrate to the peripheral circulation and to differentiate into mature endothelial cells, have been shown to be regulated by numerous miRNAs. Dysregulation of these miRNA results in dis-functional endothelial progenitor cells that may trigger deep vein thrombosis [73].

Mir-483-3p that has been upregulated in DVT patients has been shown to control the expression of serum response factor (SRF). Decreased levels of SRF results in reduced migration and tube formation and increased apoptosis of EPCs [52]. The miR-21 was shown to be directly associated with the $3^{\prime}$ UTR of FASL which encodes the Fas ligand, a transmembrane receptor that is known to induce apoptosis. Moreover, lower expression level of miR-21 in DVT patients was associated with an increase 
of recurrent DVT and post thrombotic syndrome (PTS) [48]. The proliferation of EPCs has also been shown to be associated with miR-150 which controls expression of the SRC kinase signaling inhibitor 1 (SRCIN1) [43]. Overexpression of miR-150 and concomitant decreased in the levels of SRCIN1 resulted in thrombus resolution in a murine model of venous thrombosis. and promoted angiogenesis and proliferation of EPCs.

Furthermore, it has been shown that progression of endothelial progenitor cells can be controlled by miR-126 by directly targeting the PIK3R2 gene whose gene product affects PI3K/Akt signaling. Overexpression of mir-126 enhanced the migratory and tubulogenic properties of EPCs in vitro and promoted EPCs' homing and thrombus resolution in vivo [41]. A similar effect was observed in EPCs cells upon overexpression of miR-205 that has a target site on the $3^{\prime} \mathrm{UTR}$ of the PTEN gene. Regulation of the PTEN gene product can modulate the Akt/autophagy pathway and MMP2 expression, which are essential for EPC function and DVT recanalization and resolution [47].

The inhibition of miR-195 in EPCs promoted cell proliferation, mitigation and angiogenesis by targeting the GABA type A receptor associated protein like 1 (GABARAPL1) [45]. While in another study, the high level of miR-195-5p in the blood of DVT patients has been shown to be directly associated with low expression of B-cell lymphoma 2 (Bcl-2). This miRNA may thus play a role in the development of DVT by regulating the apoptosis of vascular endothelial cells [44].

In addition to common risk factors, the studies have shown that deep vein thrombosis can be triggered by alteration of inflammatory processes including cytokines, chemokines and different types of leukocytes. It has been shown that miRNAs are the key gene regulators controlling inflammation [74]. Elevated levels of interleukin-6 (IL-6), that stimulate thrombus formation in veins, has been associated with low expression of miR-338-5 in peripheral blood mononuclear cells (PBMCs) obtained from patients with DVT [51]. Evaluation of plasma from 81 patients with lower-extremity deep vein thrombosis showed a decrease in expression of miR-103-3p and increased expression of chemokine C-X-C motif ligand 12 (CXCL12) that has a target site for this miRNA [26]. miRNA assessment in PBMCs from 45 patients with DVT and healthy donors showed down-regulation of miR-26a. MiR-26a directly targets and suppresses the expression of protein kinase $C \delta(P R K C D)$, which significantly reduces the levels of chemokine $\mathrm{C}-\mathrm{C}$ motif ligand (CCL)2 and thus inhibits activation of the nuclear factor kappa B (NF-kB) signaling pathway [49].

The use of miRNAs as reliable and predictive biomarkers to detect the early signs of deep vein thrombosis has been extensively evaluated. Evaluation of serum from 18 patients with deep vein thrombosis showed up-regulation of miR-582, miR-195 and miR-532 compared to healthy controls [46]. MiRNAs analysis of 12 DVT patients and 12 healthy donors revealed 13 miRNAs dysregulated in DVT patients. An investigation of 238 DVT patients showed significant upregulation of miR-424-5p and downregulation of miR-136-5p in patient plasma. The plasma level of miR-424-5p was associated with both D-dimer and APC-PCI complex levels [42]. D-dimer, a fiber degradation protein fragment released into blood after blot clot, is elevated in patients with thrombotic disorder and used as a biomarker to identify DVT. The studies on 30 DVT patients, 30 post-thrombotic syndrome patients and 30 healthy volunteers unveil significant dysregulation of miR-320a/b in DVT compare to both PTS or healthy groups [50].

\subsubsection{Pulmonary Embolism (PE)}

Evaluation of miR-27a/b expression in 78 patients with acute pulmonary embolism (APE) and 70 healthy donors displayed significantly higher expression of this miRNA in APE patients [57]. It has been shown that miR-27a/b target and regulate the tissue factor pathway inhibitor (TFPI) in endothelial cells thus indirectly regulating tissue factor (TF) and blood coagulation [31,75]. Evaluation of ten chronic thromboembolic pulmonary hypertension (CTEPH) patients revealed upregulation of 17 miRNAs. Among them, let-17b that was downregulated in plasma of CTEPH patients has been shown to directly target endothelin-1 (ET-1) and cause dysfunction of pulmonary arterial endothelial cells [53]. Another study on 32 APE patients and 32 healthy donors showed significant upregulation of 
miR-134 in the plasma of APE patients [55]. Studies on a group of 60 patients with acute APE and 50 healthy volunteers, showed a high level of miR-221 in APE samples compared to controls [56]. High level of miR-28 was observed in $37 \mathrm{PE}$ patients compared with normal controls [58]. Finally, miR-1233 has been shown to be selectively upregulated in acute PE compared to patients with chronic PE and healthy donors [54]. Additional studies are needed to distinguish the precise regulatory role of these miRNAs in PE and to verify which of these miRNAs may serve specific diagnostic predictors of APE.

\subsection{Arterial Thrombosis}

Arterial thrombosis is caused by a rupture of atherosclerotic plaque (rich in platelets) formed after accumulation of the lipid and lipid-laden macrophages in the artery wall [40]. The pathogenesis of arterial thrombosis is complex and is associated with numerous genetic and environmental factors related to atherosclerosis and thrombosis, as well as the interaction of the two [76]. Several reports have highlighted the role of miRNA in atherosclerosis as they fine-tune the expression of proteins involved in the progression, modulation and regulation of every stage of atherosclerosis including lipid homeostasis, signaling pathways and endothelial function [77-79]. For example, it has been suggested that the process of atherosclerotic plaque rupture may be controlled by miR-223-mediated suppression of tissue factor [30].

Platelet number and activation is linked with arterial thrombosis and coronary artery disease [80-83]. A study on patients with essential thrombocythemia (ET) who had elevated platelet counts revealed downregulation of 9 miRNAs: miR-10a, miR-28, miR-126, miR-155, miR-221, miR-222, miR-223 and miR-431 as well as upregulation of miR-9 and miR-490 in ET patients compared to healthy controls [62]. Moreover, increased mir-223 level has been also associated with lipid metabolism and high intracellular cholesterol levels that can trigger lipid metabolism-related disorders including liver steatosis and atherosclerosis [84].

In other studies, the high level of miR-126 detected in patients with coronary artery disease (CAD) was associated with high low-density lipoprotein (LDL) cholesterol levels. Interestingly, low levels of miR-126 were associated with a high level of LDL in patients who had risk factors for CAD but did not have angiographically significant CAD [66]. miR-126 has been shown to play a role in arterial remodeling by crosstalk with miR-221/222 in endothelial cells $[65,85]$. By binding to vascular cell adhesion molecule-1 (VCAM-1) miR-126 can modulate adhesion of leucocytes to endothelial cells and thus play an anti-inflammatory role. Moreover, miR-126 that is released by microparticles during EC apoptosis is linked to atherosclerosis through regulation of CXCL12. Overall, this study suggests that miR-126 can serve as a marker atherothrombotic vascular diseases [64]. Mir-19b that has been shown to target tissue factor in patients with unstable angina may also play an anti-thrombotic role [29]. An association of mir-19b with cholesterol metabolism and atherosclerotic diseases has been demonstrated [86]. Mir-19b directly targeted adenosine triphosphate (ATP)-binding cassette transporter $\mathrm{A} 1$ and its overexpression increase plaque size and lipid content.

Role of other miRNA: miR-181b in regulation of TF and arterial thrombosis was also highlighted [28]. MiR-181b indirectly regulated TF by targeting thrombin-activated NF- $\mathrm{kB}$ signaling.

Moreover, suppression of miR-124a and miR-125a and overexpression of miR-146a and miR-155 in monocytes was associated with atherothrombosis in antiphospholipid syndrome and systemic lupus erythematosus [63]. Monocyte transfections with pre-miR-124a and/or -125a caused reduction in target molecules associated with atherothrombosis. Elevated expression of miR-146a/b, miR-21, miR-34a and miR-210 was observed in atherosclerotic plaques compare to non-atherosclerotic left internal thoracic arteries [68]. Patients with stenosis showed an increase in circulating miRNA-21, miRNA-126-3p and miRNA-222 in response to cardiac stress [87]. Finally, miRNA evaluation of 8 patients with stable coronary artery disease display elevated level of miR-145 and reduced expression of miR-126, miR-17, miR-92a and miR-155 compared with healthy controls [67]. The discovery of the role of these miRNAs in arterial thrombosis may provide novel treatment options for cardiovascular diseases. 


\subsection{Coagulation Cascade and Thrombosis}

While several studies suggest that miRNA upregulation results in reduced levels of coagulation factors, numerus studies have also shown that down-regulation of the same miRNAs results in increased expression of these coagulation factors which may trigger thrombotic events.

In addition, mutations have been reported in the $3^{\prime}$ UTR of the coagulation factor genes F2, F8, F9 and F11. Genotyping of Canadian subjects ( 4485 cases of individuals with extreme low or high level of coagulation factors and 4889 controls) showed an association between some mutations in the $3^{\prime}$ UTR of the $F 2, F 8$ and $F 11$ genes with increased plasma activity of the gene-product [16]. In silico studies predicted that these mutations may disturb the binding sites of some miRNAs. Specifically, a mutation within the $3^{\prime}$ UTR of $F 8$ impeded the binding of miR-34a/c and miR-449a/b, while 6 mutations in $F 11$ 3'UTR impeded the binding of 9 miRNAs which included miR-554 [76].

In another study, reduced level of miR-145 observed in venous thrombosis patients was correlated with an increase in the level of tissue factor [27]. Experimental validation confirmed direct binding of miR-145 with the $3^{\prime}$ UTR of the TF gene.

Moreover, it has been suggested that the process of atherosclerotic plaque rupture may be controlled by miR-223-mediated suppression of TF. Overexpression or suppression of miR-223 in HUVEC cells and in mice resulted in dysregulation of tissue factor at both the mRNA and protein levels [30]. It has also been shown that miR-223 is released by exosomes of thrombin activated platelets and is critical for the regulation of atherosclerosis and endothelial implementation. The study showed that miR-223 regulated intercellular adhesion molecule 1 (ICAM-1) expression in thrombin-activated platelet-derived exosomes through NF-KB and MAPK pathways [69]. It has also been demonstrated that some miRNAs released by platelets, including miR-320b can regulate ICAM- 1 expression in endothelial cells [88].

Studies have also shown that miR-27a/b and miR-494 directly target $3^{\prime}$ UTR of tissue factor pathway inhibitor and down-regulate TFPI mRNA and protein levels in MCF7 cells (the human mammary adenocarcinoma cells). Overexpression of these miRNAs induced a procoagulant state caused by increased factor Xa generation which promote thrombotic disease [31].

Finally, polymorphisms in the fibrinogen alpha (FGA) gene have been associated with venous thromboembolism $[17,18]$. A 28 bp (Del/Ins) in the 3'UTR of the FGA gene was investigated for association with miRNAs. In silico studies identified the binding site of miR-759 within this FGA Del/Ins polymorphic fragment [89]. Studies in a hepatocellular carcinoma cell line HepG2 that endogenously expresses FGA revealed that miR-759 regulates FGA expression.

The synthesis of fibrinogen increases in response to inflammatory reaction triggered by interleukin-6 (IL-6) [90]. Interestingly, miR-18a has been shown to enhance the IL-6 mediated production of fibrinogen as well as hepatoglobin in human hepatocytes [12].

Recent studies suggest that the decrease in fibrinogen levels may be associated with miRNA-mediated regulation. Transfection of Huh7 hepatoma cells with human miRNAs identified 50 miRNAs that disrupted fibrinogen production in Huh7 cells; of these 50 miRNAs, 27 miRNAs are expressed in the human liver [14]. Among the 27 miRNAs that are expressed in the liver and regulate FI levels; 23 miRNAs downregulated while 4 miRNAs upregulated FI expression. Further studies using the luciferase assay showed that 3 miRNAs (miR-29a, miR-29b, miR-29c; all belonging to the miRNA 29 family) regulate FI expression but do not directly bind to the $3^{\prime}$ UTR of FI. On the other hand, miR-409 regulated FI expression by direct binding to fibrinogen B $\beta 3^{\prime} \mathrm{UTR}$.

Finally, an evaluation of blood samples from 123 sepsis patient that were divided into coagulation abnormal and normal patients found a correlation between upregulation of miR-122 in coagulation abnormal patients and increased levels of fibrinogen compared to the control group [13].

In addition, coagulation factors there are other proteins involved in hemostasis that can be regulated by miRNAs [91]. Examination of hemostasis-associated genes by RNA pull-down approach revealed 150 specific miRNA associations with hemostatic genes comprising procoagulant ( $F 7, F 8, F 11$, FGA, FGG and KLKB1) and anticoagulant (SERPINA10, PROZ, SERPIND1 and SERPINC1) as well 
as fibrinolytic (PLG) components. A total of 40 miRNAs were functionally confirmed to target these genes [15].

Genetic Analysis of Idiopathic Thrombophilia 2 using plasma samples from 935 subjects revealed 4 miRNAs (miR-126-3p, miR-885-5p, miR-194-5p and miR-192-5p) that were potentially associated with venous thrombosis; i.e., these miRNAs by targeting genes encoding proteins in the coagulation pathway. miR-885-5p and miR-195-5p expression was correlated with expression of Protein S and FVII. MiR-192-5p dysregulation was associated with FVII and ADAMS13, while miR-126-3p was associated with FXI [20]. Deficiency in protein S can trigger thrombosis [25,92-94]. miR-494 has been shown to directly bind to the 3'UTR and downregulate PROS1 (encoding the protein S) and protein S (PS) levels in liver Huh cells [25].

Finally, a recent study showed that Factor X (FX) deficiency has been associated with dysregulation of miR-24. The evaluation of plasma from 15 healthy volunteers and 36 severe trauma-induced coagulopathy (TIC) patients showed that TIC patients had elevated levels of miR-24, which correlated with significantly lower levels of FX compared to the healthy volunteers [23].

\section{Discussion}

The current studies have highlighted some miRNAs that are essential in thrombosis and hemostasis. As shown in Figure 1, numerous reports indicate a clear association between dysregulation of miR-145, miR-320a/b and miR-222 on thrombosis. Moreover, some miRNAs are linked to specific types of thrombosis, and may thus serve as potential biomarkers or therapeutic targets. For example, miRNAs strongly corelated with deep vein thrombosis such as miR-103a, miR-26 or miR-195 dysregulate protein critical in coagulation factors or target proteins essential for endothelial progenitor cells. Pulmonary embolism is linked with dysregulation of $\mathrm{miR} 27 \mathrm{a} / \mathrm{b}$ that target tissue factor inhibitor. On other hand, miR-126 or miR-223 that are linked to arterial thrombosis target proteins that cause endothelial dysfunction, alternation of lipid metabolism or trigger inflammation and target ICAM-1, VCAM-1, IL-6 or IL-8. In addition, four miRNAs: miR-18, miR-24, miR-30a/c/d/e and miR-494 has been shown to dysregulate key proteins involved in hemostasis. While these miRNAs have not been linked with thrombosis, they are associated with bleeding disorders. Bleeding disorders and thrombosis can both result from disturbed hemostasis; i.e., decreased and enhanced expression of coagulation proteins respectively. Consequently, we may expect that the reverse dysregulation of these miRNAs may trigger thrombotic event.

Both bleeding disorders and thrombotic events are potentially life-threatening. Both disorders arise due to a disturbance in the homeostasis of the coagulation system and involve many of the same molecular actors. Thus, miRNAs, whose principal biological function is fine-tuning of gene expression, are likely candidates for maintaining the balance between preventing both excessive bleeding and clots that could lead to thrombosis. In the last decade, many research studies have either directly or indirectly implicated miRNAs in regulating the expression of molecules involved in coagulation and/or thrombosis. In this review we have comprehensively and critically surveyed this literature.

The most common bleeding disorders are hemophilia A, B, C and VWD. While these diseases are commonly regarded as being caused by mutations in the coding regions of $F 8, F 9, F 11$ or VWF; a critical mass of research studies shows that expression of the protein products of these genes are also regulated by miRNAs. Furthermore, in the case of both hemophilia A and B there are a small group of patients $(<5 \%)$ who have no mutations in the coding and non-coding regions of the $F 8$ and $F 9$ genes. In the case of hemophilia $\mathrm{A}$ it has been demonstrated that miRNA dysregulation is a likely cause of the disease in these patients. It is however very likely that in many (possibly most) patients the reduced activity of the coagulation factors is some combination of dysfunction of the protein and reduced expression of the gene. This hypothesis is bolstered by the finding that different patients with the same missense F8 mutation may exhibit mild, moderate and severe forms of the disease [34] based on FVIII activity. 


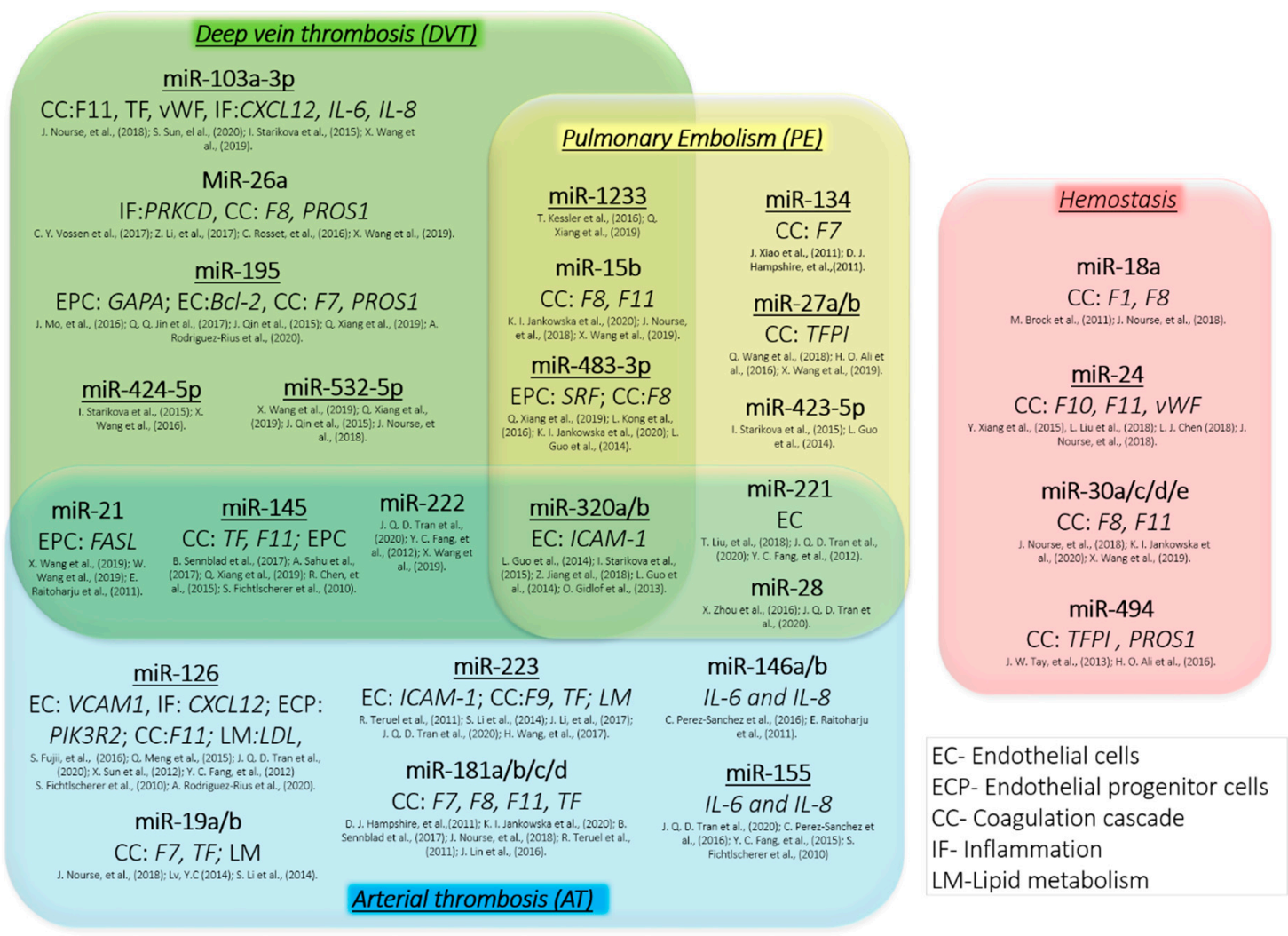

Figure 1. Role of miRNAs in thrombosis and hemostasis. The association of some miRNAs with different types of thrombosis and hemostasis along with the potential target genes (in italic) of proteins essential for coagulation cascade (CC), endothelial progenitor cell (EPC) or endothelial cell (EC) regulation, inflammation (IF) and lipid metabolism (LM). Selected miRNAs have been reported to play an important role in regulation of hemostasis in multiple independent research studies and thus are promising biomarkers (underlined) and therapeutic targets for the treatment of thrombosis and bleeding disorders.

Using either in silico or experimental methods (and often both together), a diverse set of miRNAs have been found to associate with the 3'UTRs of genes encoding coagulation factors. This is consistent with the mechanism of action of miRNAs where multiple mRNAs target the same gene and a single miRNA targets multiple genes. It is thus plausible that miRNA dysregulation may be personalized in individual patients and no single miRNA may be associated with the disease condition. Consequently, studies should endeavor to carefully and comprehensively validate the miRNAs associated with disease pathologies but there should be no expectation of consistency between different patients or between different studies.

We also reviewed the reported role(s) of miRNAs in thrombosis. Venous thromboembolism, deep vein thrombosis, pulmonary embolisms and arterial thrombosis have all been associated with dysregulated miRNAs.

As expected, many of these miRNAs target genes encoding coagulation factors as up-regulation of proteins involved in hemostasis to abnormally high-levels can lead to thrombotic events. In addition, many other genes not directly involved in the coagulation cascade have also been reported. However, in addition to genetic association studies, more detailed studies that clearly demonstrate the mechanism by which miRNAs physiologically regulate the hemostatic potential are urgently needed. Worldwide, one in four deaths is attributable to thrombosis. Understanding the role of miRNAs in thrombosis represents an untapped potential in the management and treatment of this fatal or debilitating disease. 
Author Contributions: K.I.J. performed literature review and participated in writing of the manuscript together with Z.E.S. and C.D.A. All authors have read and agreed to the published version of the manuscript.

Funding: This review received no external funding.

Acknowledgments: This project was supported by appointment to the Research Participation Program (KJ) at the Office of Blood Research and Review and the Office of Tissues and Advanced Therapies, Center for Biologics Evaluation and Research, US Food and Drug Administration, administered by the Oak Ridge Institute for Science and Education through an interagency agreement between the US Department of Energy and the FDA.

Conflicts of Interest: The authors declare no conflict of interest. The findings and conclusions in this review have not been formally disseminated by the Food and Drug Administration and should not be construed as representing any Agency determination or policy.

\section{Abbreviations}

\begin{tabular}{|c|c|}
\hline Akt & Protein kinase B \\
\hline $\mathrm{APC}$ & Activated protein $\mathrm{C}$ \\
\hline APC-PCI & Plasma concentrations of activated protein $\mathrm{C}$-inhibitor of protein $\mathrm{C}$ \\
\hline $\mathrm{APE}$ & Acute pulmonary embolism \\
\hline ATP & Adenosine triphosphate \\
\hline $\mathrm{Bcl}-2$ & B-cell lymphoma 2 \\
\hline CAD & Coronary artery disease \\
\hline CCL & Chemokine C-C motif ligand \\
\hline СТEPH & Chronic thromboembolic pulmonary hypertension \\
\hline CXCL12 & Chemokine C-X-C motif ligand 12 \\
\hline Del/Ins & Deletion-insertion \\
\hline DVT & Venous thrombosis that includes both deep vein thrombosis \\
\hline EC & Endothelial cells \\
\hline EPC & Endothelial progenitor cells \\
\hline ET-1 & Endothelin-1 \\
\hline F11 & Coagulation factor FXI \\
\hline F2 & Coagulation factor II gene \\
\hline F7 & Coagulation factor VII gene \\
\hline F8 & Coagulation factor VIII gene \\
\hline F9 & Coagulation factor IX gene \\
\hline FasL & $\begin{array}{l}\text { Fas ligant (FasL or CD95L or CD178) is a type-II transmembrane protein that } \\
\text { belongs to the tumor necrosis factor (TNF) family }\end{array}$ \\
\hline FASL & Gene encoded Fas ligand \\
\hline FGA & Fibrinogen alpha gene \\
\hline FGB & Fibrinogen beta gene \\
\hline FGG & Fibrinogen gamma gene \\
\hline FI & Coagulation factor I, fibrinogen \\
\hline FII & Prothrombin, coagulation factor II \\
\hline FIX & Coagulation factor IX \\
\hline FVII & Coagulation factor VII \\
\hline FVIII & Coagulation factor VIII \\
\hline $\mathrm{FX}$ & Coagulation factor $X$ \\
\hline FXI & Coagulation factor XI \\
\hline GABA & Gamma-aminobutyric acid receptors \\
\hline GABARAPL1 & GABA Type A receptor associated protein like 1 \\
\hline HA & Hemophilia A, coagulation FVIII deficiency \\
\hline HB & Hemophilia B, coagulation FIX deficiency \\
\hline $\mathrm{HC}$ & Hemophilia C, coagulation FXI deficiency \\
\hline HepG2 & Liver hepatocellular cells \\
\hline Huh-7 & Human liver cell line \\
\hline HUVEC & Human umbilical vein endothelial cells \\
\hline
\end{tabular}




\begin{tabular}{|c|c|}
\hline ICAM-1 & Intercellular adhesion molecule 1 \\
\hline IL-6 & Interleukin-6 \\
\hline IL-8 & Interleukin-8 \\
\hline KLKB1 & gene encoded plasma kallikrein \\
\hline LDL & Low-density lipoprotein \\
\hline MAPK & Mitogen-activated protein kinase \\
\hline MCF7 & Breast cancer cell line acronym of Michigan Cancer Foundation-7 \\
\hline miRNA & MicroRNAs \\
\hline MMP2 & Proteins of the matrix metalloproteinase \\
\hline mRNA & Messenger RNA \\
\hline $\mathrm{NF}-\kappa \mathrm{B}$ & Nuclear factor- $\kappa \mathrm{B}$ \\
\hline NMD & Nonsense-mediated mRNA decay \\
\hline OS & Osteosarcoma \\
\hline PBMC & Peripheral blood mononuclear cells \\
\hline PE & Pulmonary embolism \\
\hline PI3K & Phosphoinositide 3-kinases \\
\hline PIK3R2 & Phosphoinositide-3-kinase regulatory subunit 2 which affected PI3K/Akt \\
\hline PLG & Plasminogen, fibrinolytic protease \\
\hline PROS & Protein S gene \\
\hline PROZ & protein $\mathrm{Z}$, vitamin $\mathrm{K}$ dependent plasma glycoprotein gene \\
\hline PS & Protein S \\
\hline PTC & Premature termination codon \\
\hline PTEN & Phosphatase and tensin homolog \\
\hline PTS & Post-thrombotic syndrome \\
\hline SERPINA & Serpin family A member 1 gene \\
\hline SERPINC1 & Serpin family $\mathrm{C}$ member 1 gene \\
\hline SERPIND1 & SERPIND1 gene encoded heparin cofactor II (HCII) \\
\hline SRC & Proto-oncogene tyrosine-protein kinase Src \\
\hline SRCIN1 & SRC kinase signaling inhibitor 1 \\
\hline SRF & Serum response factor \\
\hline TGFBR1 & Transforming growth factor beta receptor 1 \\
\hline $\mathrm{TF}$ & Tissue factor, coagulation factor III \\
\hline TFPI & Tissue factor pathway inhibitor \\
\hline TIC & Trauma-induced coagulopathy patients \\
\hline TNF- $\alpha$ & Tumor necrosis factor alpha \\
\hline UTR & Untranslated regions \\
\hline VCAM-1 & Vascular cell adhesion molecule- 1 \\
\hline VWF & Von Willebrand factor \\
\hline VWD & Von Willebrand disease \\
\hline
\end{tabular}

\section{References}

1. Peter, M.E. Targeting of mRNAs by multiple miRNAs: The next step. Oncogene 2010, 29, 2161-2164. [CrossRef] [PubMed]

2. Bartel, D.P. MicroRNAs: Genomics, biogenesis, mechanism, and function. Cell 2004, 116, 281-297. [CrossRef]

3. Michlewski, G.; Caceres, J.F. Post-transcriptional control of miRNA biogenesis. RNA 2019, 25, 1-16. [CrossRef] [PubMed]

4. Davis, G.M.; Haas, M.A.; Pocock, R. MicroRNAs: Not "fine-tuners" but key regulators of neuronal development and function. Front. Neurol. 2015, 6, 245. [CrossRef] [PubMed]

5. Zhang, Z.; Qin, Y.W.; Brewer, G.; Jing, Q. MicroRNA degradation and turnover: Regulating the regulators. Wiley Interdiscip. Rev. RNA 2012, 3, 593-600. [CrossRef] [PubMed]

6. Schratt, G. Fine-tuning neural gene expression with microRNAs. Curr. Opin. Neurobiol. 2009, 19, $213-219$. [CrossRef] [PubMed] 
7. Sevignani, C.; Calin, G.A.; Siracusa, L.D.; Croce, C.M. Mammalian microRNAs: A small world for fine-tuning gene expression. Mamm. Genome 2006, 17, 189-202. [CrossRef] [PubMed]

8. Jankowska, K.I.; McGill, J.; Pezeshkpoor, B.; Oldenburg, J.; Atreya, C.D.; Sauna, Z.E. Clinical manifestation of hemophilia A in the absence of mutations in the F8 gene that encodes FVIII: Role of microRNAs. Transfusion 2020, 60, 401-413. [CrossRef] [PubMed]

9. Sarachana, T.; Dahiya, N.; Simhadri, V.L.; Pandey, G.S.; Saini, S.; Guelcher, C.; Guerrera, M.F.; Kimchi-Sarfaty, C.; Sauna, Z.E.; Atreya, C.D. Small ncRNA expression-profiling of blood from hemophilia A patients identifies miR-1246 as a potential regulator of Factor 8 gene. PLoS ONE 2015, 10, e0132433. [CrossRef]

10. Jerjes-Sanchez, C. Venous and arterial thrombosis: A continuous spectrum of the same disease? Eur. Heart J. 2005, 26, 3-4. [CrossRef]

11. Kamphuisen, P.W.; Eikenboom, J.C.; Bertina, R.M. Elevated factor VIII levels and the risk of thrombosis. Arterioscler. Thromb. Vasc. Biol. 2001, 21, 731-738. [CrossRef] [PubMed]

12. Brock, M.; Trenkmann, M.; Gay, R.E.; Gay, S.; Speich, R.; Huber, L.C. MicroRNA-18a enhances the interleukin-6-mediated production of the acute-phase proteins fibrinogen and haptoglobin in human hepatocytes. J. Biol. Chem. 2011, 286, 40142-40150. [CrossRef] [PubMed]

13. Wang, H.J.; Deng, J.; Wang, J.Y.; Zhang, P.J.; Xin, Z.; Xiao, K.; Feng, D.; Jia, Y.H.; Liu, Y.N.; Xie, L.X. Serum miR-122 levels are related to coagulation disorders in sepsis patients. Clin. Chem. Lab. Med. 2014, 52, 927-933. [CrossRef] [PubMed]

14. Fort, A.; Borel, C.; Migliavacca, E.; Antonarakis, S.E.; Fish, R.J.; Neerman-Arbez, M. Regulation of fibrinogen production by microRNAs. Blood 2010, 116, 2608-2615. [CrossRef]

15. Nourse, J.; Braun, J.; Lackner, K.; Huttelmaier, S.; Danckwardt, S. Large-scale identification of functional microRNA targeting reveals cooperative regulation of the hemostatic system. J. Thromb. Haemost. 2018, 16, 2233-2245. [CrossRef]

16. Vossen, C.Y.; Van Hylckama Vlieg, A.; Teruel-Montoya, R.; Salloum-Asfar, S.; De Haan, H.; Corral, J.; Reitsma, P.; Koeleman, B.P.C.; Martinez, C. Identification of coagulation gene $3^{\prime} \mathrm{UTR}$ variants that are potentially regulated by microRNAs. Br. J. Haematol. 2017, 177, 782-790. [CrossRef]

17. Carter, A.M.; Catto, A.J.; Kohler, H.P.; Ariens, R.A.; Stickland, M.H.; Grant, P.J. alpha-fibrinogen Thr312Ala polymorphism and venous thromboembolism. Blood 2000, 96, 1177-1179. [CrossRef]

18. Remijn, J.A.; Van Wijk, R.; De Groot, P.G.; Van Solinge, W.W. Nature of the fibrinogen Aalpha gene TaqI polymorphism. Thromb. Haemost. 2001, 86, 935-936.

19. Hampshire, D.J.; Goodeve, A.C. The international society on thrombosis and haematosis von Willebrand disease database: An update. Semin. Thromb. Hemost. 2011, 37, 470-479. [CrossRef]

20. Rodriguez-Rius, A.; Lopez, S.; Martinez-Perez, A.; Souto, J.C.; Soria, J.M. Identification of a plasma MicroRNA profile associated with venous thrombosis. Arterioscler. Thromb. Vasc. Biol. 2020, 40. [CrossRef]

21. Rosset, C.; Vieira, I.A.; Salzano, F.M.; Bandinelli, E. A germline variant affects putative miRNA-binding sites at the F8 3'UTR and acts as a potential haemophilia A phenotype modifier in Southern Brazilian patients. Haemophilia 2016, 22, e327-e329. [CrossRef] [PubMed]

22. Wang, G.; Chai, B.; Yang, L. MiR-128 and miR-125 regulate expression of coagulation Factor IX gene with nonsense mutation by repressing nonsense-mediated mRNA decay. Biomed. Pharmacother. 2016, 80, 331-337. [CrossRef] [PubMed]

23. Chen, L.J.; Yang, L.; Cheng, X.; Xue, Y.K.; Chen, L.B. Overexpression of miR-24 Is Involved in the Formation of Hypocoagulation State after Severe Trauma by Inhibiting the Synthesis of Coagulation Factor X. Dis Markers 2017, 2017, 3649693. [CrossRef] [PubMed]

24. Sennblad, B.; Basu, S.; Mazur, J.; Suchon, P.; Martinez-Perez, A.; Van Hylckama Vlieg, A.; Truong, V.; Li, Y.; Gadin, J.R.; Tang, W.; et al. Genome-wide association study with additional genetic and post-transcriptional analyses reveals novel regulators of plasma factor XI levels. Hum. Mol. Genet. 2017, 26, 637-649. [CrossRef]

25. Tay, J.W.; Romeo, G.; Hughes, Q.W.; Baker, R.I. Micro-ribonucleic Acid 494 regulation of protein S expression. J. Thromb. Haemost. 2013, 11, 1547-1555. [CrossRef]

26. Sun, S.; Chai, S.; Zhang, F.; Lu, L. Overexpressed microRNA-103a-3p inhibits acute lower-extremity deep venous thrombosis via inhibition of CXCL12. IUBMB Life 2020, 72, 492-504. [CrossRef] 
27. Sahu, A.; Jha, P.K.; Prabhakar, A.; Singh, H.D.; Gupta, N.; Chatterjee, T.; Tyagi, T.; Sharma, S.; Kumari, B.; Singh, S.; et al. MicroRNA-145 impedes thrombus formation via targeting tissue factor in venous thrombosis. EBioMedicine 2017, 26, 175-186. [CrossRef]

28. Lin, J.; He, S.; Sun, X.; Franck, G.; Deng, Y.; Yang, D.; Haemmig, S.; Wara, A.K.; Icli, B.; Li, D.; et al. MicroRNA-181b inhibits thrombin-mediated endothelial activation and arterial thrombosis by targeting caspase recruitment domain family member 10. FASEB J. 2016, 30, 3216-3226. [CrossRef]

29. Li, S.; Ren, J.; Xu, N.; Zhang, J.; Geng, Q.; Cao, C.; Lee, C.; Song, J.; Li, J.; Chen, H. MicroRNA-19b functions as potential anti-thrombotic protector in patients with unstable angina by targeting tissue factor. J. Mol. Cell Cardiol. 2014, 75, 49-57. [CrossRef]

30. Li, S.; Chen, H.; Ren, J.; Geng, Q.; Song, J.; Lee, C.; Cao, C.; Zhang, J.; Xu, N. MicroRNA-223 inhibits tissue factor expression in vascular endothelial cells. Atherosclerosis 2014, 237, 514-520. [CrossRef]

31. Ali, H.O.; Arroyo, A.B.; Gonzalez-Conejero, R.; Stavik, B.; Iversen, N.; Sandset, P.M.; Martinez, C.; Skretting, G. The role of microRNA-27a/b and microRNA-494 in estrogen-mediated downregulation of tissue factor pathway inhibitor alpha. J. Thromb. Haemost. 2016, 14, 1226-1237. [CrossRef] [PubMed]

32. Xiang, Y.; Cheng, J.; Wang, D.; Hu, X.; Xie, Y.; Stitham, J.; Atteya, G.; Du, J.; Tang, W.H.; Lee, S.H.; et al. Hyperglycemia repression of miR-24 coordinately upregulates endothelial cell expression and secretion of von Willebrand factor. Blood 2015, 125, 3377-3387. [CrossRef] [PubMed]

33. Liu, L.; Pan, J.; Wang, H.; Ma, Z.; Yin, J.; Yuan, F.; Yuan, Q.; Zhou, L.; Liu, X.; Zhang, Y.; et al. von Willebrand factor rescued by miR-24 inhibition facilitates the proliferation and migration of osteosarcoma cells in vitro. Biosci. Rep. 2018, 38. [CrossRef] [PubMed]

34. Johnsen, J.M.; Fletcher, S.N.; Huston, H.; Roberge, S.; Martin, B.K.; Kircher, M.; Josephson, N.C.; Shendure, J.; Ruuska, S.; Koerper, M.A.; et al. Novel approach to genetic analysis and results in 3000 hemophilia patients enrolled in the My Life, Our Future initiative. Blood Adv. 2017, 1, 824-834. [CrossRef] [PubMed]

35. Selvaraj, S.R.; Pipe, S.W. Not in the genotype: Can unexplained hemophilia A result from "micro(RNA) management"? Transfusion. 2020, 60, 227-228. [CrossRef] [PubMed]

36. Pezeshkpoor, B.; Berkemeier, A.C.; Czogalla, K.J.; Oldenburg, J.; El-Maarri, O. Evidence of pathogenicity of a mutation in 3' untranslated region causing mild haemophilia A. Haemophilia 2016, 22, 598-603. [CrossRef]

37. Duga, S.; Salomon, O. Congenital factor XI deficiency: An update. Semin. Thromb. Hemost. 2013, 39, 621-631. [CrossRef]

38. Wheeler, A.P.; Gailani, D. Why factor XI deficiency is a clinical concern. Expert Rev. Hematol. 2016, 9, 629-637. [CrossRef]

39. Salloum-Asfar, S.; Teruel-Montoya, R.; Arroyo, A.B.; Garcia-Barbera, N.; Chaudhry, A.; Schuetz, E.; Luengo-Gil, G.; Vicente, V.; Gonzalez-Conejero, R.; Martinez, C. Regulation of coagulation factor XI expression by microRNAs in the human liver. PLoS ONE 2014, 9, e111713. [CrossRef]

40. Mackman, N. Triggers, targets and treatments for thrombosis. Nature 2008, 451, 914-918. [CrossRef]

41. Meng, Q.; Wang, W.; Yu, X.; Li, W.; Kong, L.; Qian, A.; Li, C.; Li, X. Upregulation of MicroRNA-126 contributes to endothelial progenitor cell function in deep vein thrombosis via its target PIK3R2. J. Cell. Biochem. 2015, 116, 1613-1623. [CrossRef] [PubMed]

42. Wang, X.; Sundquist, K.; Elf, J.L.; Strandberg, K.; Svensson, P.J.; Hedelius, A.; Palmer, K.; Memon, A.A.; Sundquist, J.; Zoller, B. Diagnostic potential of plasma microRNA signatures in patients with deep-vein thrombosis. Thromb. Haemost. 2016, 116, 328-336. [CrossRef] [PubMed]

43. Wang, W.; Zhu, X.; Du, X.; Xu, A.; Yuan, X.; Zhan, Y.; Liu, M.; Wang, S. MiR-150 promotes angiogensis and proliferation of endothelial progenitor cells in deep venous thrombosis by targeting SRCIN1. Microvasc. Res. 2019, 123, 35-41. [CrossRef] [PubMed]

44. Jin, Q.Q.; Sun, J.H.; Du, Q.X.; Lu, X.J.; Zhu, X.Y.; Fan, H.L.; Holscher, C.; Wang, Y.Y. Integrating microRNA and messenger RNA expression profiles in a rat model of deep vein thrombosis. Int. J. Mol. Med. 2017, 40, 1019-1028. [CrossRef]

45. Mo, J.; Zhang, D.; Yang, R. MicroRNA-195 regulates proliferation, migration, angiogenesis and autophagy of endothelial progenitor cells by targeting GABARAPL1. Biosci. Rep. 2016, 36. [CrossRef]

46. Qin, J.; Liang, H.; Shi, D.; Dai, J.; Xu, Z.; Chen, D.; Chen, X.; Jiang, Q. A panel of microRNAs as a new biomarkers for the detection of deep vein thrombosis. J. Thromb. Thrombolysis 2015, 39, 215-221. [CrossRef] 
47. Sun, L.L.; Xiao, L.; Du, X.L.; Hong, L.; Li, C.L.; Jiao, J.; Li, W.D.; Li, X.Q. MiR-205 promotes endothelial progenitor cell angiogenesis and deep vein thrombosis recanalization and resolution by targeting PTEN to regulate Akt/autophagy pathway and MMP2 expression. J. Cell. Mol. Med. 2019, 23, 8493-8504. [CrossRef]

48. Du, X.; Hong, L.; Sun, L.; Sang, H.; Qian, A.; Li, W.; Zhuang, H.; Liang, H.; Song, D.; Li, C.; et al. miR-21 induces endothelial progenitor cells proliferation and angiogenesis via targeting FASLG and is a potential prognostic marker in deep venous thrombosis. J. Transl. Med. 2019, 17, 270. [CrossRef]

49. Li, Z.; Ni, J. Role of microRNA-26a in the diagnosis of lower extremity deep vein thrombosis in patients with bone trauma. Exp. Ther. Med. 2017, 14, 5069-5074. [CrossRef]

50. Jiang, Z.; Ma, J.; Wang, Q.; Wu, F.; Ping, J.; Ming, L. Combination of circulating miRNA-320a/b and D-dimer improves diagnostic accuracy in deep vein thrombosis patients. Med. Sci. Monit. 2018, 24, 2031-2037. [CrossRef]

51. Zhang, Y.; Zhang, Z.; Wei, R.; Miao, X.; Sun, S.; Liang, G.; Chu, C.; Zhao, L.; Zhu, X.; Guo, Q.; et al. IL (Interleukin)-6 contributes to deep vein thrombosis and is negatively regulated by miR-338-5p. Arterioscler. Thromb. Vasc. Biol. 2020, 40, 323-334. [CrossRef] [PubMed]

52. Kong, L.; Hu, N.; Du, X.; Wang, W.; Chen, H.; Li, W.; Wei, S.; Zhuang, H.; Li, X.; Li, C. Upregulation of miR-483-3p contributes to endothelial progenitor cells dysfunction in deep vein thrombosis patients via SRF. J. Transl. Med. 2016, 14, 23. [CrossRef] [PubMed]

53. Guo, L.; Yang, Y.; Liu, J.; Wang, L.; Li, J.; Wang, Y.; Liu, Y.; Gu, S.; Gan, H.; Cai, J.; et al. Differentially expressed plasma microRNAs and the potential regulatory function of Let-7b in chronic thromboembolic pulmonary hypertension. PLoS ONE 2014, 9, e101055. [CrossRef] [PubMed]

54. Kessler, T.; Erdmann, J.; Vilne, B.; Bruse, P.; Kurowski, V.; Diemert, P.; Schunkert, H.; Sager, H.B. Serum microRNA-1233 is a specific biomarker for diagnosing acute pulmonary embolism. J. Transl. Med. 2016, 14, 120. [CrossRef]

55. Xiao, J.; Jing, Z.C.; Ellinor, P.T.; Liang, D.; Zhang, H.; Liu, Y.; Chen, X.; Pan, L.; Lyon, R.; Liu, Y.; et al. MicroRNA-134 as a potential plasma biomarker for the diagnosis of acute pulmonary embolism. J. Transl. Med. 2011, 9, 159. [CrossRef]

56. Liu, T.; Kang, J.; Liu, F. Plasma levels of microRNA-221 (miR-221) are increased in patients with acute pulmonary embolism. Med. Sci. Monit. 2018, 24, 8621-8626. [CrossRef]

57. Wang, Q.; Ma, J.; Jiang, Z.; Wu, F.; Ping, J.; Ming, L. Diagnostic value of circulating microRNA-27a/b in patients with acute pulmonary embolism. Int. Angiol. 2018, 37, 19-25. [CrossRef]

58. Zhou, X.; Wen, W.; Shan, X.; Qian, J.; Li, H.; Jiang, T.; Wang, W.; Cheng, W.; Wang, F.; Qi, L.; et al. MiR-28-3p as a potential plasma marker in diagnosis of pulmonary embolism. Thromb. Res. 2016, 138, 91-95. [CrossRef]

59. Starikova, I.; Jamaly, S.; Sorrentino, A.; Blondal, T.; Latysheva, N.; Sovershaev, M.; Hansen, J.B. Differential expression of plasma miRNAs in patients with unprovoked venous thromboembolism and healthy control individuals. Thromb. Res. 2015, 136, 566-572. [CrossRef]

60. Wang, X.; Sundquist, K.; Svensson, P.J.; Rastkhani, H.; Palmer, K.; Memon, A.A.; Sundquist, J.; Zoller, B. Association of recurrent venous thromboembolism and circulating microRNAs. Clin. Epigenet. 2019, 11, 28. [CrossRef]

61. Xiang, Q.; Zhang, H.X.; Wang, Z.; Liu, Z.Y.; Xie, Q.F.; Hu, K.; Zhang, Z.; Mu, G.Y.; Ma, L.Y.; Jiang, J.; et al. The predictive value of circulating microRNAs for venous thromboembolism diagnosis: A systematic review and diagnostic meta-analysis. Thromb. Res. 2019, 181, 127-134. [CrossRef] [PubMed]

62. Tran, J.Q.D.; Pedersen, O.H.; Larsen, M.L.; Grove, E.L.; Kristensen, S.D.; Hvas, A.M.; Nissen, P.H. Platelet microRNA expression and association with platelet maturity and function in patients with essential thrombocythemia. Platelets 2020, 31, 365-372. [CrossRef] [PubMed]

63. Perez-Sanchez, C.; Aguirre, M.A.; Ruiz-Limon, P.; Barbarroja, N.; Jimenez-Gomez, Y.; De la Rosa, I.A.; Rodriguez-Ariza, A.; Collantes-Estevez, E.; Segui, P.; Velasco, F.; et al. Atherothrombosis-associated microRNAs in Antiphospholipid syndrome and Systemic Lupus Erythematosus patients. Sci. Rep. 2016, 6, 31375. [CrossRef] [PubMed]

64. Fujii, S.; Sugiura, T.; Dohi, Y.; Ohte, N. MicroRNA in atherothromobosis: Is it useful as a disease marker? Thromb. J. 2016, 14, 21. [CrossRef]

65. Fang, Y.C.; Yeh, C.H. Role of microRNAs in vascular remodeling. Curr. Mol. Med. 2015, 15, 684-696. [CrossRef] 
66. Sun, X.; Zhang, M.; Sanagawa, A.; Mori, C.; Ito, S.; Iwaki, S.; Satoh, H.; Fujii, S. Circulating microRNA-126 in patients with coronary artery disease: Correlation with LDL cholesterol. Thromb. J. 2012, 10, 16. [CrossRef]

67. Fichtlscherer, S.; De Rosa, S.; Fox, H.; Schwietz, T.; Fischer, A.; Liebetrau, C.; Weber, M.; Hamm, C.W.; Roxe, T.; Muller-Ardogan, M.; et al. Circulating microRNAs in patients with coronary artery disease. Circ. Res. 2010, 107, 677-684. [CrossRef]

68. Raitoharju, E.; Lyytikainen, L.P.; Levula, M.; Oksala, N.; Mennander, A.; Tarkka, M.; Klopp, N.; Illig, T.; Kahonen, M.; Karhunen, P.J.; et al. miR-21, miR-210, miR-34a, and miR-146a/b are up-regulated in human atherosclerotic plaques in the Tampere Vascular Study. Atherosclerosis 2011, 219, 211-217. [CrossRef]

69. Li, J.; Tan, M.; Xiang, Q.; Zhou, Z.; Yan, H. Thrombin-activated platelet-derived exosomes regulate endothelial cell expression of ICAM-1 via microRNA-223 during the thrombosis-inflammation response. Thromb. Res. 2017, 154, 96-105. [CrossRef]

70. Franco, R.F.; Reitsma, P.H. Genetic risk factors of venous thrombosis. Hum. Genet. 2001, 109, 369-384. [CrossRef]

71. Hembrom, A.A.; Srivastava, S.; Garg, I.; Kumar, B. MicroRNAs in venous thrombo-embolism. Clin. Chim. Acta 2020, 504, 66-72. [CrossRef] [PubMed]

72. Jiang, Z.; Ma, J.; Wang, Q.; Wu, F.; Ping, J.; Ming, L. Circulating microRNA expression and their target genes in deep vein thrombosis: A systematic review and bioinformatics analysis. Medicine (Baltimore) 2017, 96, e9330. [CrossRef] [PubMed]

73. Li, W.D.; Li, X.Q. Endothelial progenitor cells accelerate the resolution of deep vein thrombosis. Vascul. Pharmacol. 2016, 83, 10-16. [CrossRef] [PubMed]

74. Tahamtan, A.; Teymoori-Rad, M.; Nakstad, B.; Salimi, V. Anti-inflammatory MicroRNAs and their potential for inflammatory diseases treatment. Front. Immunol. 2018, 9, 1377. [CrossRef]

75. Arroyo, A.B.; Salloum-Asfar, S.; Perez-Sanchez, C.; Teruel-Montoya, R.; Navarro, S.; Garcia-Barbera, N.; Luengo-Gil, G.; Roldan, V.; Hansen, J.B.; Lopez-Pedrera, C.; et al. Regulation of TFPIalpha expression by $\mathrm{miR}-27 \mathrm{a} / \mathrm{b}-3 \mathrm{p}$ in human endothelial cells under normal conditions and in response to androgens. Sci. Rep. 2017, 7, 43500. [CrossRef]

76. Voetsch, B.; Loscalzo, J. Genetic determinants of arterial thrombosis. Arterioscler. Thromb. Vasc. Biol. 2004, 24, 216-229. [CrossRef]

77. Menghini, R.; Stohr, R.; Federici, M. MicroRNAs in vascular aging and atherosclerosis. Ageing Res. Rev. 2014, 17, 68-78. [CrossRef]

78. Hosin, A.A.; Prasad, A.; Viiri, L.E.; Davies, A.H.; Shalhoub, J. MicroRNAs in atherosclerosis. J. Vasc. Res. 2014, 51, 338-349. [CrossRef]

79. Feinberg, M.W.; Moore, K.J. MicroRNA regulation of atherosclerosis. Circ. Res. 2016, 118, 703-720. [CrossRef]

80. Tomaiuolo, M.; Brass, L.F.; Stalker, T.J. Regulation of platelet activation and coagulation and its role in vascular injury and arterial thrombosis. Interv. Cardiol. Clin. 2017, 6, 1-12. [CrossRef]

81. Pafili, K.; Penlioglou, T.; Mikhailidis, D.P.; Papanas, N. Mean platelet volume and coronary artery disease. Curr. Opin. Cardiol. 2019, 34, 390-398. [CrossRef] [PubMed]

82. Icli, A.; Aksoy, F.; Turker, Y.; Uysal, B.A.; Alpay, M.F.; Dogan, A.; Nar, G.; Varol, E. Relationship between mean platelet volume and pulmonary embolism in patients with deep vein thrombosis. Heart Lung Circ. 2015, 24, 1081-1086. [CrossRef] [PubMed]

83. Warny, M.; Helby, J.; Birgens, H.S.; Bojesen, S.E.; Nordestgaard, B.G. Arterial and venous thrombosis by high platelet count and high hematocrit: 108521 individuals from the Copenhagen General Population Study. J. Thromb. Haemost. 2019, 17, 1898-1911. [CrossRef] [PubMed]

84. Novak, J.; Olejnickova, V.; Tkacova, N.; Santulli, G. Mechanistic role of MicroRNAs in coupling lipid metabolism and atherosclerosis. Adv. Exp. Med. Biol. 2015, 887, 79-100. [CrossRef] [PubMed]

85. Nazari-Jahantigh, M.; Wei, Y.; Schober, A. The role of microRNAs in arterial remodelling. Thromb. Haemost. 2012, 107, 611-618. [CrossRef] [PubMed]

86. Lv, Y.C.; Tang, Y.Y.; Peng, J.; Zhao, G.J.; Yang, J.; Yao, F.; Ouyang, X.P.; He, P.P.; Xie, W.; Tan, Y.L.; et al. MicroRNA-19b promotes macrophage cholesterol accumulation and aortic atherosclerosis by targeting ATP-binding cassette transporter A1. Atherosclerosis 2014, 236, 215-226. [CrossRef]

87. Jansen, F.; Schafer, L.; Wang, H.; Schmitz, T.; Flender, A.; Schueler, R.; Hammerstingl, C.; Nickenig, G.; Sinning, J.M.; Werner, N. Kinetics of circulating MicroRNAs in response to cardiac stress in patients with coronary artery disease. J. Am. Heart Assoc. 2017, 6. [CrossRef] 
88. Gidlof, O.; Van der Brug, M.; Ohman, J.; Gilje, P.; Olde, B.; Wahlestedt, C.; Erlinge, D. Platelets activated during myocardial infarction release functional miRNA, which can be taken up by endothelial cells and regulate ICAM1 expression. Blood 2013, 121, 3908-3917. [CrossRef]

89. Chen, Z.; Nakajima, T.; Tanabe, N.; Hinohara, K.; Sakao, S.; Kasahara, Y.; Tatsumi, K.; Inoue, Y.; Kimura, A. Susceptibility to chronic thromboembolic pulmonary hypertension may be conferred by miR-759 via its targeted interaction with polymorphic fibrinogen alpha gene. Hum. Genet. 2010, 128, 443-452. [CrossRef]

90. Nesbitt, J.E.; Fuller, G.M. Transcription and translation are required for fibrinogen mRNA degradation in hepatocytes. Biochim. Biophys. Acta 1991, 1089, 88-94. [CrossRef]

91. Teruel, R.; Corral, J.; Perez-Andreu, V.; Martinez-Martinez, I.; Vicente, V.; Martinez, C. Potential role of miRNAs in developmental haemostasis. PLoS ONE 2011, 6, e17648. [CrossRef] [PubMed]

92. Campello, E.; Spiezia, L.; Radu, C.M.; Bulato, C.; Gavasso, S.; Tormene, D.; Woodhams, B.; Dalla Valle, F.; Simioni, P. Circulating microparticles and the risk of thrombosis in inherited deficiencies of antithrombin, protein C and protein S. Thromb. Haemost. 2016, 115, 81-88. [CrossRef] [PubMed]

93. Rosenberg, R.D.; Bauer, K.A. Thrombosis in inherited deficiencies of antithrombin, protein C, and protein S. Hum. Pathol. 1987, 18, 253-262. [CrossRef]

94. Siddiqi, F.A.; Tepler, J.; Fantini, G.A. Acquired protein S and antithrombin III deficiency caused by nephrotic syndrome: An unusual cause of graft thrombosis. J. Vasc. Surg. 1997, 25, 576-580. [CrossRef]

(C) 2020 by the authors. Licensee MDPI, Basel, Switzerland. This article is an open access article distributed under the terms and conditions of the Creative Commons Attribution (CC BY) license (http://creativecommons.org/licenses/by/4.0/). 